\title{
MODELING OF PARAMETERS FOR FOREST FIRE RISK ZONE MAPPING
}

\author{
Kapil Pandey ${ }^{1, *}$, S. K. Ghosh ${ }^{1}$ \\ Department of Civil Engineering, IIT Roorkee, Uttrakhand, India - pandeykapil2003@gmail.com, scangfce@iitr.ac.in
}

Commission V, SS: Natural Resources Management

KEY WORDS: Criteria Based Weight, Risk Zonation, Fire sensitivity, Topographic map, AHP.

\begin{abstract}
:
Forest fire has been regarded as one of the major reasons for the loss of biodiversity and dreadful conditions of environment. Global warming is also increasing the incidence of forest fire at an alarming rate. That's why, one need to understand the complex biophysical parameters, which are responsible for this disaster. As it is difficult to predict forest fire, fire risk zone map can be useful for combating the forest fire. So the main aim of this study is to generate a Fire risk model to map fire risk zone using Remote Sensing \& GIS technique. Pauri Garhwal District, located in Uttarakhand, India, has been selected for this study as it continually faces the problem of forest fire. Landsat- 8 data of $18^{\text {th }}$ April, 2016 have been used for land use land cover mapping. Slope and other information have been derived from topographic maps and field information. For thematic and topographic information analysis ArcGIS and ERDAS Imagine software have been used. Forest fire risk model was generated by using AHP method, where each category was assigned subjective weight according to their sensitivity to fire. Three categories of forest fire risk ranging from very high to low were derived. The generated forest fire risk model was found to be in strong agreement with actual fire-affected sites.
\end{abstract}

\section{INTRODUCTION}

Forest fire is one of the major causes of degradation of forests. About $50 \%$ of the forest in Uttarakhand is prone to high frequency of fire, mostly due to human actions (Babu et. al., 2016). In India, major reason of forest fires are human activities and natural reason of fires, such as, lightning are very less (Bahuguna et. al., 2002). Forest fire risk zones are locations where a fire is expected to start, and from where it can easily spread to adjoining areas. Forest fire risk problem and its solution can be achieved by forest fire risk zone mapping (Jaiswal et.al, 2002). By considering the behavior of forest fire, the factors that contribute to making an environment fire prone, and the factors that influence fire behavior are essential for forest fire (Chuvieco et. al., 1989). The GIS-based model may be good approach, where a major part of the forested land is being influenced by the population (Malik et. al., 2013).

In this study, an effort has been made to generate a forest fire risk zone map by using the Remote sensing and GIS techniques and to propose a Fuzzy based Modeling of Parameters Index for Fire Risk Zone. This criteria (Fuzzy) based method is good approach for Indian conditions, where a major part of the forest land is encroach by human beings (Roy et. al., 1991; Jain et. al., 1996). Such maps will help forest department officials to prevent or minimize fire risk behavior within the forest and take proper action when fire breaks out (Chuvieco and Sales, 1996).

\section{STUDY AREA}

Pauri Garhwal district having an area of 5,230 Km. ${ }^{2}$ and located between $29^{\circ} 45^{\prime}$ to $30^{\circ} 15^{\prime}$ North Latitude and $78^{\circ} 24^{\prime}$ to $79^{\circ}$ 23' East Longitude has been selected for study. As per information available from Forest Survey of India website; it is found that in the year 2016, there are 1639 events recorded for Pauri Garhwal district out of a total of 6289 forest fire events recorded to the whole of Uttarakhand State.

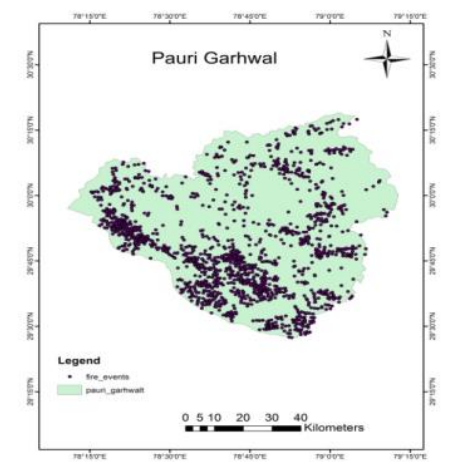

Figure 1: Study area - Pauri Garhwal

\section{DATA AND SOFTWARE USED}

The data used in this study is Landsat- 8 of $18^{\text {th }}$ April, 2016, (Path 146 and Row 39), Cartosat DEM of 30m resolution of the study area was downloaded from USGS earth explorer website and Bhuvan website respectively. To process the data, ERDAS imagine 2014 and Arc GIS 10.2.1 software has been used for analysis of data.

\section{METHODOLOGY}

The flowchart for the methodology is shown in Figure 2.

\footnotetext{
${ }^{*}$ Corresponding author
} 


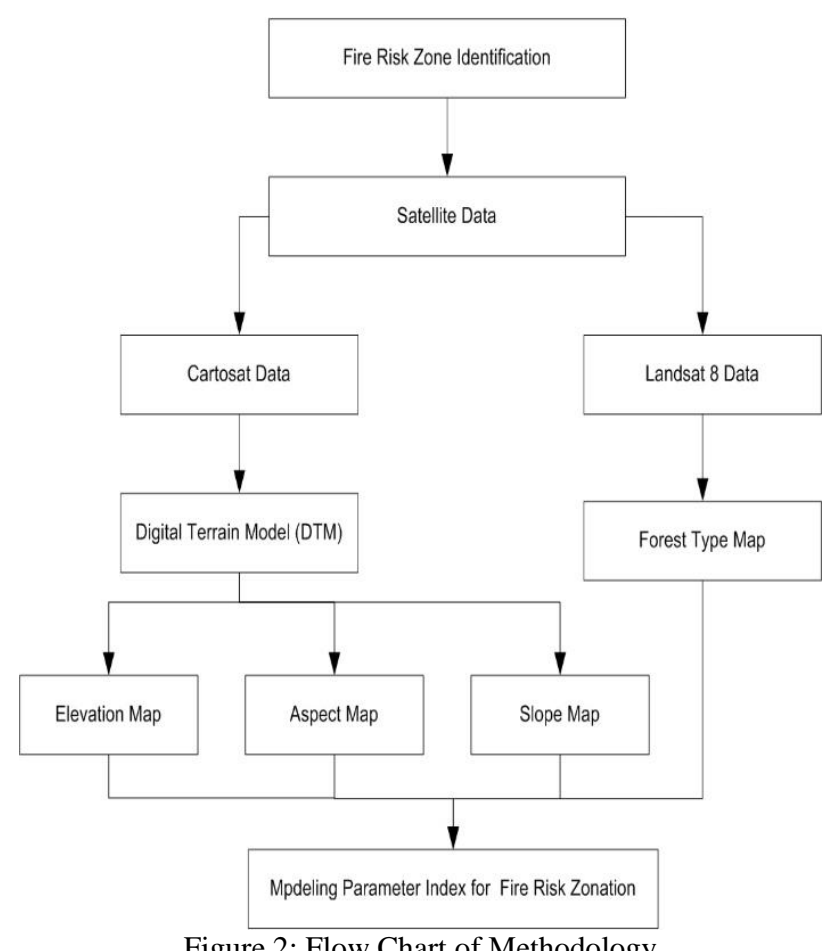

Figure 2: Flow Chart of Methodology

Toposheet required for the study area has been identified from Survey of India (SOI) website. Boundary of Pauri Garhwal was digitized from toposheet with the help of Arc GIS software, The boundary of study area has been used to subset image of Pauri Garhwal from Landsat- 8 data of $18^{\text {th }}$ April, 2016. The satellite data has been rectify with toposheet using first order nearest neighbor resampling technique. A total of 30 ground points have been used to register the image with RMSE error of less than 0.5 pixel, with the help of ERDAS.

To generate the land use land cover classification of study image, Maximum Likelihood classification technique has been used. Further, forest cover has been extracted from the classified map. Cartosat data has been used to classify Digital Elevation Model (DEM) for the study area. The topographical factors such as, slope and aspect layers have been derived from DEM.

\section{GENERATION OF THEMATIC LAYERS}

As, the thematic layers are the primary requirement for spatial data input in GIS it is necessary that all information must be in the form of map. Remote sensing and GIS, with limited ground checks, are suitable for generating resource maps.

\subsection{Generation of Land Use Land Cover Map}

In this study, forest type mapping employed the use of Landsat8 data, which was free from cloud cover. Supervised classification technique was used for land used land cover classification of study area, total 7 classes were identified that are mentioned in Table 1 and shown in Fig.3. Total area has been found $5329 \mathrm{~km}^{2}$ and same has been classified with an overall accuracy of 82 present. From classified map, the area is dominated by forest (nearly $93 \%$ ) with low density forest being $25.79 \%$ and high density being $67.87 \%$ of study area. After this, image has been reclassified into 3 classes such as High density forest, Low density forest and other than forest, to generate the forest type map, shown in Fig.4.

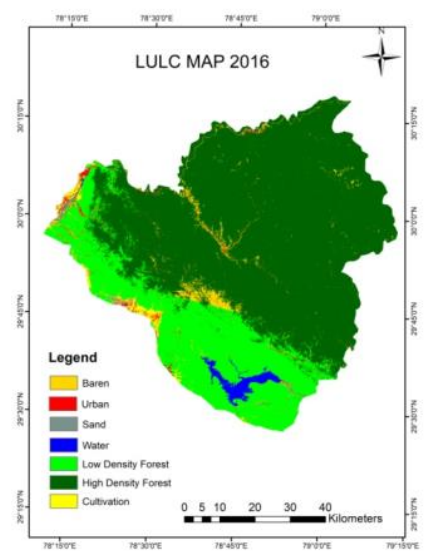

Figure 3: LULC Map 2016

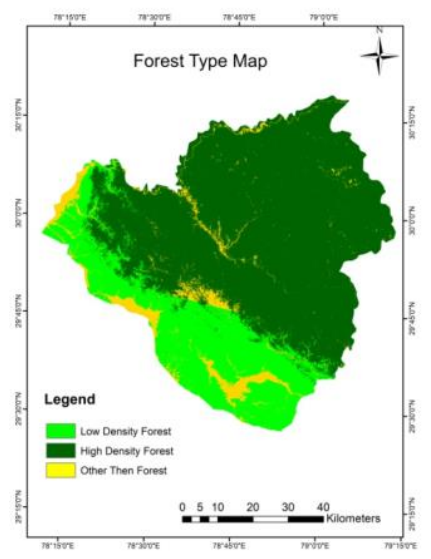

Figure 4: Forest Type Map

Table 1: Statistics for classified map 2016

\begin{tabular}{|l|l|c|c|}
\hline $\begin{array}{l}\text { Sr. } \\
\text { No. }\end{array}$ & Class Name & $\begin{array}{l}\text { Area } \\
\left(\mathbf{k m}^{2}\right)\end{array}$ & $\begin{array}{l}\text { \% } \\
\text { Area }\end{array}$ \\
\hline 1 & Barren & 103.63 & 1.94 \\
\hline 2 & Urban & 46.40 & 0.87 \\
\hline 3 & Sand & 28.90 & 0.54 \\
\hline 4 & Water & 74.25 & 1.39 \\
\hline 5 & Low Density Forest & 1374.30 & 25.79 \\
\hline 6 & High Density Forest & 3616.98 & 67.87 \\
\hline 7 & Agriculture/Cultivation & 84.54 & 1.59 \\
\hline \multicolumn{2}{|r|}{ Total area } & $\mathbf{5 3 2 9}$ & $\mathbf{1 0 0}$ \\
\hline
\end{tabular}

\subsection{Generation of Slope, Elevation and Aspect from DEM} (Digital Elevation Model)

A subset of Cartosat DEM of study area was extracted from Cartosat 1 with the help of boundary vector layer. Resampling and reprojection of DEM has been carried out. Slope, Elevation and Aspect maps, (Fig.5, Fig.6 and Fig.7 respectively), have been generated and reclassified with the help of ERDAS IMAGINE and Arc GIS software using topographic analysis tool. Fig. 8 represents the relationship between area and elevation (Area Elevation Curve) of study region. The areal distribution of Elevation and Aspect has been graphically represented in Fig. 9 and Fig. 11 respectively, and shown in Table 2 and Table 3. 


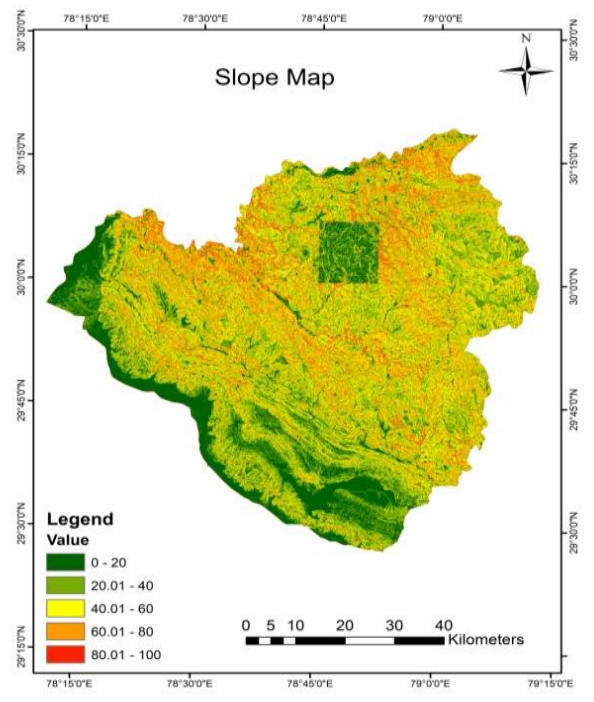

Figure 5: Slope Map

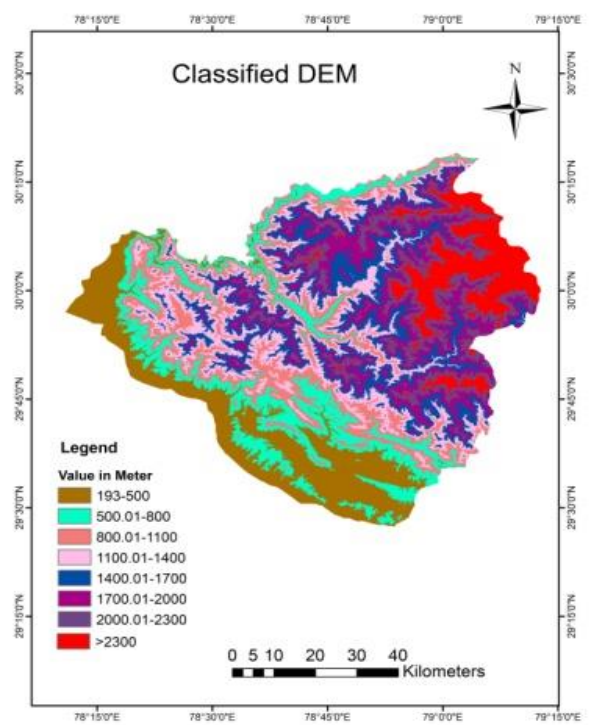

Figure 6: Elevation Map

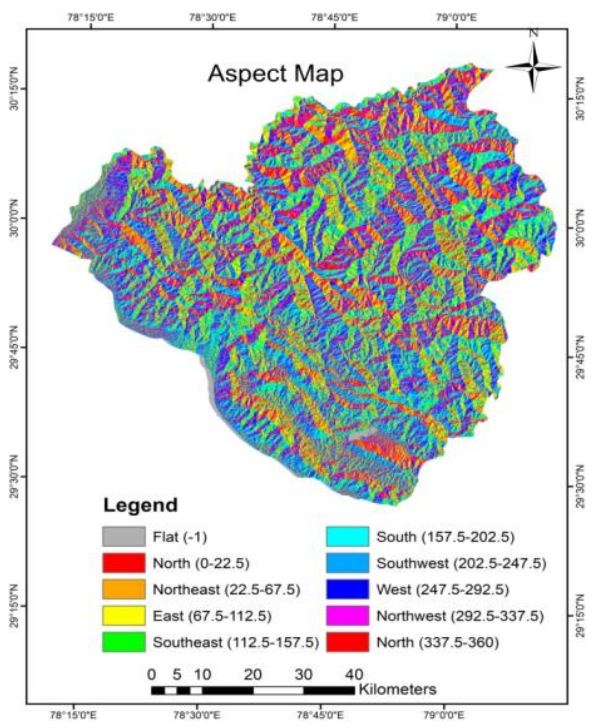

Figure 7: Aspect Map

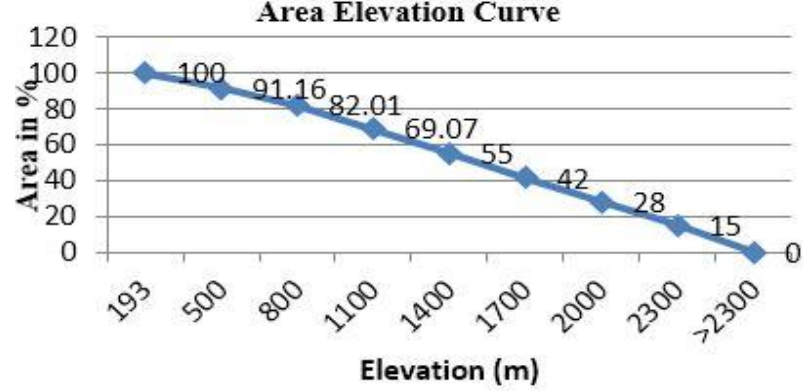

Figure 8: Area Elevation Curve

\subsection{Road buffer map and Settlement buffer map}

A road buffer map and settlement location map was prepared using SOI topographic sheet. Create buffer tool of GIS was used to create different buffer zones around the road and settlement locations. Buffer zones of 100, 200, 300, 400 and 500 meter intervals were created around the road, shown in Fig. $9 \mathrm{a}$ and $9 \mathrm{~b}$ respectively. Similarly perimeters of 1000,2000 , 3000 and 4000meter for settlement buffer were created around the settlement, shown in Fig. 10a and 10b respectively.

Roads provide the passage to fire due to human and vehicular activities and movement on it. The forest area near to roads is more fire prone then the forest at distance. The forests in study area are traversed by many roads that allow local persons to become the cause of forest fire. People carelessly throw matches and burning biddies which are the main reason of forest fire in study area.

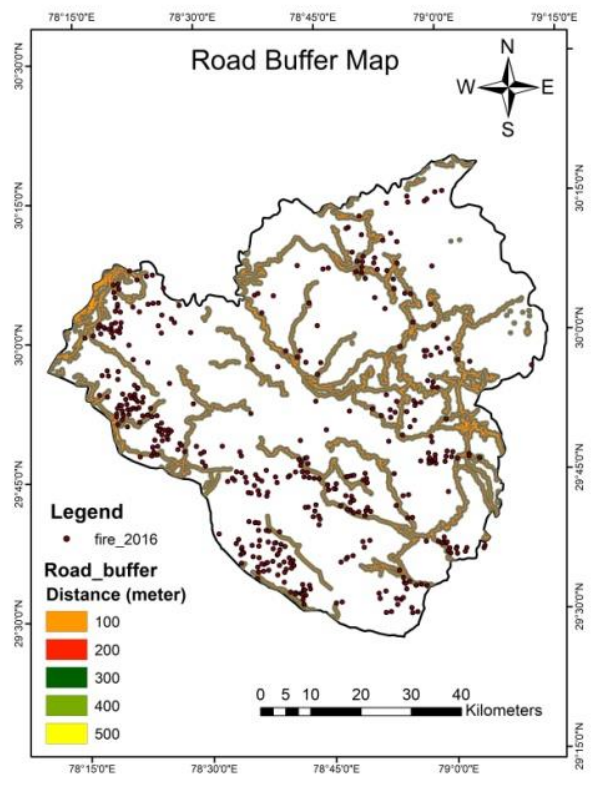

Figure: 9a Road Buffer Map 


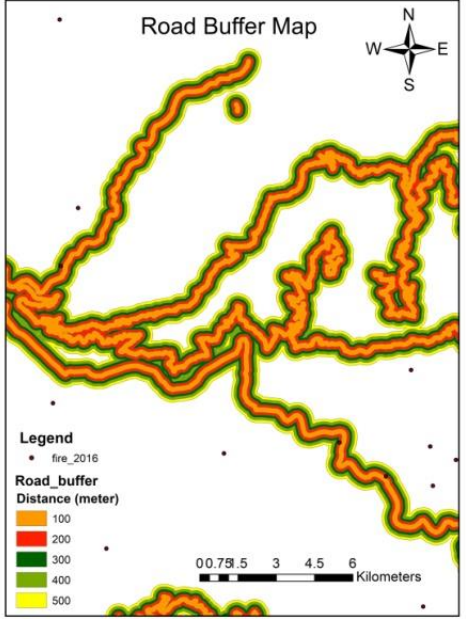

Figure: 9b Road Buffer Map

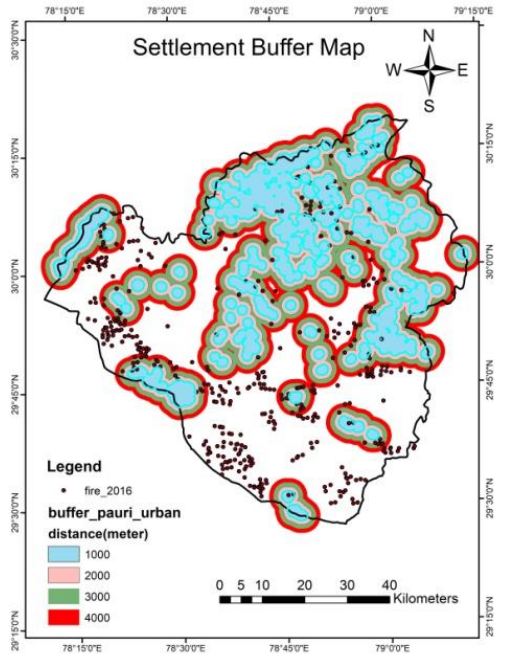

Figure: 10a Settlement Buffer Map

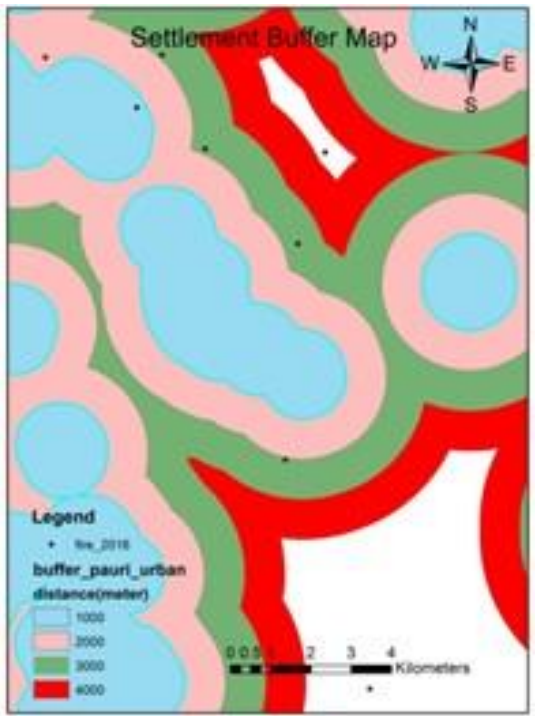

Figure: 10b Settlement Buffer Map
Forested area near settlement is more fire prone due to habitation activities that can lead accidental fire. Very few habitations are located within the forest but they can cause of some forest fire.

\section{GENERATION OF WEIGHT AND RANKING FACTORS FOR DIFFERENT GROUPS}

The factors that influence the fire risk in an area were analyzed such as: Elevation, Aspect, Slope, Forest type, accessibility and road network. After determining the influence of each factor on forest fire risk, the different classes of each factor were given suitable weights. A higher weight indicates that the factor has a high degree of influence on the fire risk in an area.

Rankings were assigned in the range of 0 to 9 with respect to occurrence of fire events in different elevations range shown in Table 2. Similarly, this was followed to assign rankings to different -different direction of aspect in the ranges from 1 to 7 shown in Table 3. Though human activity does not influence the fire behavior but it is a key variable for ignition of fire. Road inside the forest may cause fire due to human activities as distance increases from road to deep forest it decreases the probability of human induced fire. Slope also does not influence the ignition of fire but completely control the behavior of fire. Suppression operation is also governed by slope. Forest types are the main cause for fire vulnerability. A forest fire cannot occur until inflammable material present. Deodar and Chir pine trees are mostly present in study region and these species are more sensitive to fire. Each class of forest type was rated according to their composition of species (Malik Tahir et.al. ,2013). Rankings to factors as: Settlement, Road, slope and Fuel type, are shown in Table 4, 5, 6 and 7 respectively.

Table 2: Ranking w.r.t. to Elevation

\begin{tabular}{|c|l|c|c|c|c|c|}
\hline S.No. & Value & $\begin{array}{c}\text { Area } \\
(\mathbf{K m})\end{array}$ & $\begin{array}{c}\text { Area } \\
(\boldsymbol{\%})\end{array}$ & $\begin{array}{c}\text { No. of } \\
\text { Fire } \\
\text { Events }\end{array}$ & $\begin{array}{c}\text { \% of } \\
\text { Fire } \\
\text { Events }\end{array}$ & Ranking \\
\hline 1 & $\begin{array}{l}193- \\
500\end{array}$ & 809.07 & 15.18 & 112 & 26.29 & 8 \\
\hline 2 & $\begin{array}{c}500.01- \\
800\end{array}$ & 691.96 & 12.98 & 149 & 34.98 & 9 \\
\hline 3 & $\begin{array}{l}800.01- \\
1100\end{array}$ & 724.43 & 13.59 & 67 & 15.73 & 7 \\
\hline 4 & $\begin{array}{l}1100.0 \\
1-1400\end{array}$ & 731.16 & 13.72 & 22 & 5.16 & 4 \\
\hline 5 & $\begin{array}{l}1400.0 \\
1-1700\end{array}$ & 723.88 & 13.58 & 28 & 6.57 & 5 \\
\hline 6 & $\begin{array}{l}1700.0 \\
1-2000\end{array}$ & 689.85 & 12.95 & 37 & 8.69 & 6 \\
\hline 7 & $\begin{array}{l}2000.0 \\
1-2300\end{array}$ & 487.75 & 9.15 & 11 & 2.58 & 3 \\
\hline 8 & $>2300$ & 470.91 & 8.84 & NIL & 0 & 0 \\
\hline TOTAL & $\mathbf{5 3 2 9}$ & $\mathbf{1 0 0}$ & $\mathbf{4 2 6}$ & $\mathbf{1 0 0}$ & \\
\hline
\end{tabular}


Table 3: Ranking w.r.t. to Aspect

\begin{tabular}{|c|c|c|c|c|c|c|}
\hline S.No. & Value & $\begin{array}{c}\text { Area } \\
\left(\mathbf{K m}^{2}\right)\end{array}$ & $\begin{array}{c}\text { Area } \\
(\%)\end{array}$ & $\begin{array}{l}\text { No. of } \\
\text { Fire } \\
\text { Events }\end{array}$ & $\begin{array}{c}\% \text { of } \\
\text { Fire } \\
\text { Events }\end{array}$ & Ranking \\
\hline 1 & Flat & 66.54 & 1.25 & 5 & 1.17 & 1 \\
\hline 2 & North & 666.49 & 12.51 & 41 & 9.62 & 2 \\
\hline 3 & $\begin{array}{c}\text { North } \\
\text { East }\end{array}$ & 660.09 & 12.39 & 37 & 8.69 & 2 \\
\hline 4 & East & 625.08 & 11.73 & 54 & 12.68 & 5 \\
\hline 5 & $\begin{array}{c}\text { South } \\
\text { East }\end{array}$ & 615.11 & 11.54 & 62 & 14.55 & 7 \\
\hline 6 & South & 690.01 & 12.95 & 69 & 16.2 & 7 \\
\hline 7 & $\begin{array}{l}\text { South } \\
\text { West }\end{array}$ & 700.25 & 13.14 & 58 & 13.62 & 6 \\
\hline 8 & West & 659.25 & 12.37 & 52 & 12.21 & 4 \\
\hline 9 & $\begin{array}{l}\text { North } \\
\text { West }\end{array}$ & 646.18 & 12.13 & 48 & 11.27 & 3 \\
\hline \multicolumn{2}{|c|}{ TOTAL } & 5329 & 100 & 426 & 100 & \\
\hline
\end{tabular}

Table 4: Ranking w.r.t. to Settlement Buffer

\begin{tabular}{|c|c|c|}
\hline S.No. & $\begin{array}{c}\text { Settlement Corridor } \\
\text { (meter) }\end{array}$ & Ranking \\
\hline 1 & $<1000$ & 7 \\
\hline 2 & $1000-2000$ & 6 \\
\hline 3 & $2000-3000$ & 4 \\
\hline 4 & $3000-4000$ & 3 \\
\hline
\end{tabular}

Table 5: Ranking w.r.t. to Road Buffer

\begin{tabular}{|c|c|c|}
\hline S.No. & $\begin{array}{c}\text { Road Corridor } \\
\text { (meter) }\end{array}$ & Ranking \\
\hline 1 & $<100$ & 8 \\
\hline 2 & $100-200$ & 7 \\
\hline 3 & $200-300$ & 6 \\
\hline 4 & $300-400$ & 4 \\
\hline 5 & $400-500$ & 3 \\
\hline
\end{tabular}

Table 6: Ranking w.r.t. to Slope

\begin{tabular}{|c|c|c|}
\hline S.No. & Slope(\%) & Ranking \\
\hline 1 & $<20$ & 8 \\
\hline 2 & $20-40$ & 7 \\
\hline 3 & $40-60$ & 6 \\
\hline 4 & $60-80$ & 5 \\
\hline 5 & $80-100$ & 2 \\
\hline
\end{tabular}

Table 7: Ranking w.r.t. to Forest Type (Malik et. al., 2013)

\begin{tabular}{|c|c|c|}
\hline S.No. & Fuel Type & Ranking \\
\hline 1 & Deciduous Forest & $2-9$ \\
\hline 2 & Degraded Forest & $1-8$ \\
\hline 3 & Moist Sal Forest & $1-6$ \\
\hline 4 & Plantation & $1-4$ \\
\hline
\end{tabular}

\section{MODELING PARAMETER INDEX FOR FIRE RISK ZONE (MPIFRZ)}

Based on sensitivity to forest fire, different classes in the thematic maps were labeled as high, moderate and low. Then suitable weights were assigned to the different-different parameters that are mentioned in Table 8. After that all the thematic layers were integrated using union operation of GIS. The equation used for the parameter modeling for fire risk mapping is:
MPIFRZ=

$\underline{(9 * \mathrm{FTIi}=1-12+8 * \mathrm{SLIj}=1-4+7 * \mathrm{ASIK}=1-4+6 * \mathrm{ELIl}=1-7+5 * \mathrm{RDIm}=1-5+4 * \mathrm{STIn}=1-5)}$

where MPIFRZ is Index of fire risk

FTI $=$ Forest type Index (with $1-12$ classes), having weight factor 9

SLI = Slope Index (with 1-4 classes), having weight factor 8 ASI $=$ Aspect Index (with 1-4 classes), having weight factor 7 ELI= Elevation Index (with 1-7 classes), having weight factor 6 RDI= Road Index (with 1-5 classes), having weight factor 5 STI= Settlement Index (with 1-5 classes), having weight factor 4

The superscripts $\mathrm{i}, \mathrm{j}, \mathrm{k}, \mathrm{l}, \mathrm{m}$ and $\mathrm{n}$ indicate subclasses in thematic layers that are based on importance to determine the fire risk zones. Finally, criterion-based analysis was carried out to create the fire risk zone map.

Table :8 Weight and Ranking of Class and Sub class Parameters

\begin{tabular}{|c|c|c|c|c|}
\hline S.No. & Parameters & Classes & Ranking & $\begin{array}{l}\text { Fire } \\
\text { Sensitivity }\end{array}$ \\
\hline \multirow{12}{*}{1} & \multirow{12}{*}{$\begin{array}{l}\text { Forest Type } \\
(\text { Weight }=9 \text { ) }\end{array}$} & \multirow{3}{*}{$\begin{array}{l}\text { Deciduous } \\
\text { Forest }\end{array}$} & 9 & High \\
\hline & & & 4 & Moderate \\
\hline & & & 2 & Low \\
\hline & & \multirow{3}{*}{$\begin{array}{l}\text { Degraded } \\
\text { Forest }\end{array}$} & 8 & High \\
\hline & & & 3 & Moderate \\
\hline & & & 1 & Low \\
\hline & & \multirow{3}{*}{$\begin{array}{l}\text { Moist } \\
\text { Forest }\end{array}$} & 6 & High \\
\hline & & & 3 & Moderate \\
\hline & & & 1 & Low \\
\hline & & \multirow[t]{3}{*}{ Plantation } & 4 & High \\
\hline & & & 2 & Moderate \\
\hline & & & 1 & Low \\
\hline \multirow{5}{*}{2} & \multirow{5}{*}{$\begin{array}{c}\text { Slope } \\
(\text { Weight }=8)\end{array}$} & $<20$ & 8 & High \\
\hline & & $20-40$ & 7 & High \\
\hline & & $40-60$ & 6 & Moderate \\
\hline & & $60-80$ & 5 & Moderate \\
\hline & & $80-100$ & 2 & Low \\
\hline \multirow{9}{*}{3} & \multirow{9}{*}{$\begin{array}{c}\text { Aspect } \\
(\text { Weight }=7)\end{array}$} & Flat & 1 & Low \\
\hline & & North & 2 & Low \\
\hline & & North East & 2 & Low \\
\hline & & East & 5 & Moderate \\
\hline & & South East & 7 & High \\
\hline & & South & 7 & High \\
\hline & & South West & 6 & High \\
\hline & & West & 4 & Moderate \\
\hline & & North West & 3 & Moderate \\
\hline \multirow{8}{*}{4} & \multirow{8}{*}{$\begin{array}{c}\text { Elevation } \\
\text { (Weight= 6) }\end{array}$} & $193-500$ & 8 & High \\
\hline & & $500.01-800$ & 9 & High \\
\hline & & $\begin{array}{l}800.01- \\
1100\end{array}$ & 7 & Moderate \\
\hline & & $\begin{array}{l}1100.01- \\
1400\end{array}$ & 4 & Moderate \\
\hline & & $\begin{array}{l}1400.01- \\
1700\end{array}$ & 5 & Moderate \\
\hline & & $\begin{array}{l}1700.01- \\
2000\end{array}$ & 6 & Low \\
\hline & & $\begin{array}{l}2000.01- \\
2300\end{array}$ & 3 & Low \\
\hline & & $>2300$ & 0 & Low \\
\hline \multirow{3}{*}{5} & \multirow{3}{*}{$\begin{array}{c}\text { Road } \\
(\text { Weight }=5)\end{array}$} & $<100$ & 8 & High \\
\hline & & $100-200$ & 7 & High \\
\hline & & $200-300$ & 6 & Moderate \\
\hline
\end{tabular}




\begin{tabular}{|c|l|l|l|l|}
\hline \multirow{3}{*}{6} & $300-400$ & 4 & Moderate \\
\cline { 3 - 5 } & & $400-500$ & 3 & Low \\
\hline \multirow{4}{*}{6} & \multirow{3}{*}{$\begin{array}{c}\text { Settlement } \\
(\text { Weight }=4)\end{array}$} & $<1000$ & 7 & High \\
\cline { 3 - 5 } & & $1000-2000$ & 6 & High \\
\cline { 3 - 5 } & & $2000-3000$ & 4 & Moderate \\
\cline { 3 - 5 } & & $3000-4000$ & 3 & Low \\
\hline
\end{tabular}

Using the MPIFRZ model thematic layers were integrated and forest fire risk zone were created by grouping the polygons of integrated layers into different risk zones. Criteria based analysis has performed to generate the lower value 48 and higher value 157 of forest fire risk zone index. These criteria based analysis classifies the risk zone map into three classes Shown in Table 9.

Table :9 Fire Risk Zones

\begin{tabular}{|c|c|c|}
\hline Fire Risk Zone & Degree of risk & Area in\% \\
\hline I & High & 25 \\
\hline II & Moderate & 32 \\
\hline III & Low & 43 \\
\hline
\end{tabular}

\section{RESULTS AND CONCLUSION}

A Risk zonation map showed in Fig. 11 shows that degraded forest type and deciduous type forest falls on high and moderate fire risk category due to having high fuel content whereas moist forest were falls in low fire risk category. Due to receiving high amount of sun rays for the whole day, it makes warmer and dry condition of southern and western aspect than other aspects. Fire can definitely be averted by using preventive measures. It is beneficial to have a fire risk zone map to avert possible forest fire risk disaster. It is to be helpful to the Forest Department, as this type of forest fire risk zone map would make possible the department to arrange and set up an appropriate fire-fighting plan for the areas that are more prone to fire damage. These types of map can help in planning the main roads, additional roads, paths, etc. and can lead to a consistent transport system to efficiently fight with small and large forest fires.

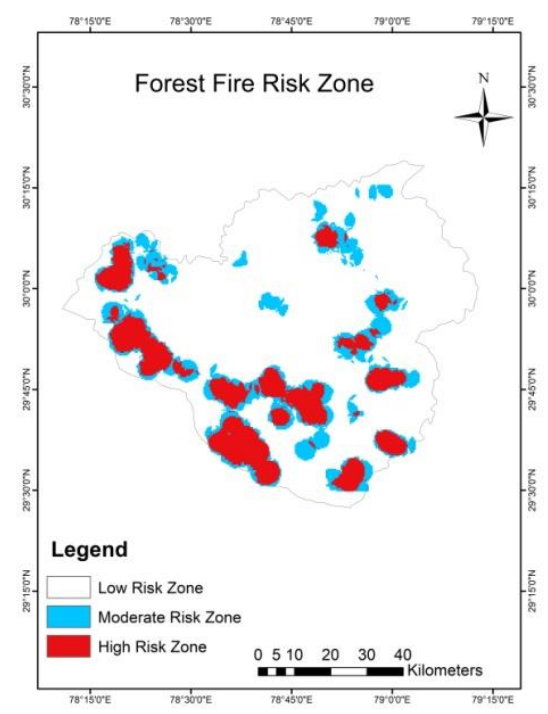

Figure: 11 Fire Risk Zone Map

\section{ACKNOWLEDGEMENT}

The first author would like to express his special thanks to QIP Centre, IIT Roorkee, All India Council for Technical Education (AICTE), New Delhi for sponsoring the research and Govt.
College of Engineering \& Technology, Bikaner (Raj.) for granting the study leave to carry out doctoral research work.

\section{REFERENCES}

Babu KV, S., Roy, A. and Prasad, P.R., 2016. Forest fire risk modeling in Uttarakhand Himalaya using TERRA satellite datasets. European Journal of Remote Sensing, 49(1), pp.381395.

Bahuguna V.K. and Singh S. 2002 - Fire situation in India. International Forest Fire News, 26: pp.23-27.

Chuvieco, E. and Congalton, R.G., 1989. Application of remote sensing and geographic information systems to forest fire hazard mapping. Remote sensing of Environment, 29(2), pp.147-159.

Chuvieco, E. and Salas, J., 1996. Mapping the spatial distribution of forest fire danger using GIS. International Journal of Geographical Information Science, 10(3), pp.333345 .

Jain, A., Ravan, S.A., Singh, R.K., Das, K.K. and Roy, P.S., 1996. Forest fire risk modelling using remote sensing and geographic information system. Current Science, pp.928-933.

Jaiswal, R.K., Mukherjee, S., Raju, K.D. and Saxena, R., 2002. Forest fire risk zone mapping from satellite imagery and GIS. International Journal of Applied Earth Observation and Geoinformation, 4(1), pp.1-10.

Malik, T., Rabbani, G. and Farooq, M., 2013. Forest fire risk zonation using remote sensing and GIS technology in Kansrao Forest Range of Rajaji National Park, Uttarakhand, India. International Journal of Advanced Remote Sensing and GIS, 2(1), pp.pp-86.

Roy, N. and Porwal, M.C., 2004. Forest Fire Risk Zonation using Geo-spatial Modeling in Part of Rajaji National Park, India. Asian Journal of Geoinformatics, 5(2). 